\title{
Sinergi Motif Batik Eco-Print dan Asesoris Sospeso untukPeningkatan Produktifitas UKM Batik dan UKM Asesoris
}

\author{
Lindiawati $^{1}$, Linda Purnama Sari ${ }^{2}$, Dewi Ayu Wulandari ${ }^{3}$ \\ ${ }^{1}$ Prodi Manajemen, STIE Perbanas Surabaya, Jl. Nginden Semolo 34-36, Surabaya, 60118 \\ E-mail: lindi@perbanas.ac.id \\ ${ }^{2}$ Prodi Manajemen, STIE Perbanas Surabaya, Jl. Nginden Semolo 34-36, Surabaya, 60118 \\ E-mail: linda@perbanas.ac.id \\ ${ }^{3}$ Prodi Manajemen, STIE Perbanas Surabaya, Jl. Nginden Semolo 34-36, Surabaya, 60118 \\ E-mail: dewiayu.wulandari@perbanas.ac.id
}

\begin{abstract}
The development trend of batik is not separated from the development trend of accessories, because the display becomes more elegant batik with batik asesoris.Motif supported and accessories designs continue to evolve with the creativity of the human mind and the changing tastes of Painting developed pasar.Batik Jumputan Ujung Galuh Surabaya SMEs also experienced the phenomenon this. Over the five years to develop batik SMEs jumputan with batik painting technique with the results with a strong color. At first the interest is pretty good, but after five years of sales are not growing. The same thing experienced by SMEs Vitrie which makes accessories brooches and necklaces with stones and borci main material. Many competitors that use other types of stone, bone, wood, scraps, metal and pearls make these SMEs to compete. This community service program is made to synergize the ecoprint technique to develop jumputan painting batik creations with accessory alloy with sospeso technique of cloth are eco-print.Ecoprint is made by applying directly vegetables and fresh flowers on the fabric and then processed with a color amplifier. While sospeso accessories made from batik patchwork eco-print by taking motifs vegetables and flowers were arranged with the help of plastic and heating. Synergies of this motif batik creations and accessories provide an elegant and attract the market. SME's second product in the last four months has been following the exhibition of products of national level and began to demand the upper-middle market with a sales increase of $10 \%$ compared to an average of four years earlier.
\end{abstract}

Keywords —: Synergy; eco-print batik; accessories; sospeso.

\section{PENDAHULUAN}

Batik dan asesoris merupakan dua hal yang tidak bisa dipisahkan. Tampilan batik akan lebih anggun apabila didukung oleh asesoris. Sebaliknya, asesoris, khususnya asesorisdengan desain etnis, akan terlihat kuat keindahannya apabila dipadu dengan batik. Seringkali apabila batik yang sudah mulai jenuh permintaannya, kemudian dipadupadan dengan asesoris dalam presentasinya atau dalam kemasannya akan menimbulkan ketertarikan bagi konsumen.

Hal ini juga dialami oleh batik jumputan lukis khas Surabaya sudah banyak diminati konsumen kalangan remaja maupun dewasa.Keunggulan produk batik jumputan yang juga dikenal dengan batik Jumputan Surabaya ini adalah karena motifnya bertema khasanah sumber daya kota Surabaya dan warnanya yang sangat kuat.Seiring perjalanan waktu permintaan batik jumputan lukis ini makin banyak.Sejak diproduksi pada tahun 2014 sampai dengan 2016 penjualan terus meningkat karena motif yang unik. Rata-rata produk masih berskala kecil dengan rata-rata penjualan per tahun 12,5 juta (2014-2017). Namun mulai bulan 8 (2017)-triwulan I-2018 tidak menunjukkan peningkatan penjualan, bahkan di beberapa bulan berikutnya terjadi penurunan. Minat pasar beralih pada motif batik lain yang bernuansa warna lembut dan alami. Faktor eksternal yang terkait dengan kondisi sosial yatu selera pasar ini merupakan faktor yang tidak dapat dikendalikan oleh UKM ini (Fleisher, Craig S. \& Bensoussan, 2003).

Pengalaman yang serupa juga dialami oleh pengrajin asesoris yaitu Vitri Accessories.UKM ini bahkan mencatat omset yang lebih kecil karena harga bros dan kalung lebih murah daripada harga batik. Pada periode tahun yang sama dengan UKM Batik Ujung Galuh yaitu 2014-2016 rata-rata omzet 6 juta per tahun.

Penampilan batik didukung oleh asesoris, maka presentasi keduanya secara bersamaan juga dapat menimbulkan dayatarik yang lebih tinggi.Dengan pemikiran ini, kedua pengrajin ini berusaha melakukan product bundling. Product bundlingmerupakan penjualan dua atau lebih produk yang berbeda dalam satu paket (Ge, Zhang, Qian, \& Yuan, 2017; Sprott, Czellar, \& Spangenberg, 2009; Stremersch \& Tellis, 2002). Kedua pengrajin menjual produk dengan memasangkan asesoris pada batik sehingga menjadi satu kesatuan(bundling).

Product bundling ini diharapkan dapat lebih menarik konsumen untuk memberli, sehingga akan berdampak pada omzet dan profit yang lebih tinggi. Dalam banyak riset telah dikaji bahwa product bundling lebih menguntungkan (Prasad, Venkatesh, \& Mahajan, 2017; Xu, Xu, Wang, \& He, 2018; Ye, Xie, Wu, \& Lui, 2017).Namun product bundling ini meskipun menghasilkan omzet yang cukup bagus yaitu 5-7 juta per bulan, namun hanya berlangsung sekitar 4 bulan terakhir di tahun 2017 dan setelah Volume 3 Nomor 2 September 2018, DAYA - MAS | 65 
Website : http://dayamas.unmermadiun.ac.id/index.php/dayamas

itu penjualan kembali stagnan. Dari dokumen foto dan beberapa koleksi produk yang di-bundling menunjukkan bahwa bundling tersebut sekedar menggabungkan dua macam produk tanpa menggunakan konsep seni yang mempertimbangkan keserasian sebuah karya seni, sehingga minat pasar kecil dan segera hilang.

Ide product bundling ini sebenarnya menarik karena menginspirasi pengrajin untuk mensinergikan kedua produk tidak di saat memasarkan saja, tetapi dari pengembangan desain awal produk seharusnya memang harus sudah diselearaskan nilai tampilan seninya. Dengan pengembangan batik jumputan lukis yang dikombinasi dengan ecoprint, kemudian perca ecoprintini dapat dikreasikan dengan teknik sospeso menjadi asesoris yang memiliki tema yang senada dengan tambahan materi lain seperti tembaga bakar, clay, atau batu.

Permasalahan yang dihadapipengrajin Batik Jumputan Lukisdan pengrajin asesoris adalah bahwa penjualan yang tidak berkembang yang disebabkan oleh berubahanya selera pasar terhadap produk batik warna kuat ke batik dengan warna lembut serta munculnya pesaing asesoris dari bahan yang sangat bervariatif dan lebih murah.

Motif Batik Jumputan Lukis dan desain aksesories yang selama ini dijual di satu outlet dan bundling, belum memberikan menunjukkan desain yang saling melengkapi.Bundling masih sekedar memadupadan seadanya saja. Jika didesain secara matching akan memberi daya saing produk yang tinggi.

Fenomema bisnis yang dihadapi pengrajin ini merupakan refleksi dari sebuah siklus industri dimana sebuah perkembangan produk dimulai dari tahap pengenalan (introduction) ke pasar, tahap pertumbuhan (growth) yaitu mendapat respon pasar dengan terjadinya pembelian, tahap kejenuhan produk (mature) yaitu tidak ada pertumbuhan penjualan, tahap adalah penurunan (decline) dan produk akan mati. Namun dalam teori analisis lingkungan internal perusahaan terkait dengan siklus produk dalam suatu industri ini juga memunculkan adanya titik terjadinya inovasi produk yang akan memotong tahap mature ke tahap decline sehingga muncul pengembangan produk yang akan memasuki tahap pengenalan (introduction) ke pasar lagi (Pearce, John A. \& Robinson, 2003) Kedua UKM ini harus melakukan inovasi karena selera pasar sudah berubah. Seiring dengan perubahan sosial dalam masyarakat, perilaku konsumen (consumer behaviour) sangat rentang mengalami pergeseran yang berdampak pada sikap yang berbeda pula terhadap produk yang akhirnya keputusan yang diambil terhadap pembelian atas produk tersebut tidak terjadi (Schiffman, L.G, Wisenblit, 2015).

Terkait dengan siklus industi, industry batik dan asesoris ini merupkan industry yang sarat dengan inovasi karena karaketistik produknya yang sangat berbeda-beda (highly differentiated) (Pearce, John A. \& Robinson, 2003). Dengan melakukan inovasi produk sesuai dengan keinginan pasar, maka produk ini mengandung nilai (value) yang memang diminati segmen pasar. Dengan kesesuaian nilai ini diharapkan konsumen akan memutuskan untuk membeli produk kedua UKM ini (Kottler, P, Armstrong, 2018)

Dengan mempertimbangkan fenomena yang dihadapi pengrajin yang produknya berada pada siklus jenuh (mature) dalam suatu siklus suatu industri respon pasar yang mulai stagnan karena banyak motif batik dan desain asesories baru dari pesaing yang sangat beragam, maka dilakukan inovasi untuk melakukan sinergi inspirasi motif batik dan desain aksesories (bertukar insprirasi). Untuk itu perlu dikembangkan pengetahuan dan ketrampilan untuk meningkatkan kemampuan mengembangkan motif batik dan desain aksesories.

Inovasi yang dikembangkan oleh kedua UKM ini adalah pengembangkan motif batik ecoprint oleh UKM Ujung Galuh dan pengembangan desain aksesories dengan teknik Sospeso yang berbahan dasar perca ecoprint, oleh UKM Vitrie Asesoris.

Nilai inovasi bagi UKM Batik adalah tumbuhnya insprirasi dan kemampuan mengembangkan produk yang semula berupa jumputan lukis, kemudian berkembang ke motif ecoprint dengan pewarnaan alam sehingga menghasilkan batik yang lebih anggun dengan warna alami. Sedangkan nilai inovasi bagi UKM asesoris adalah pemanfaatan perca bati eco-print untuk dijadikan asesoris dengan teknis sospeso yng bisa menghasilkan karya seni yang spesifik dan bernilai jual tinggi.

\section{METODE}

Metode pengembangan inovasi produk UKM Batik dan UKM Asesoris dilakukan dengan mengikuti pelatihan untuk mengembangkan ide kreatif serta ketrampilan mengembangkan motif batik dan desain asesoris yang dapat memenuhi selera pasar. Metode pelaksanaan pelatihan bagi UKM Ujung Galuh adalah dengan mempelajari pembuatan batik ecoprint, sedangkan UKM Vitrie Accessories membelajari pengembangan desain asesoris dengan teknik sospeso yang menggunakan perca dari batik ecoprint.

\section{A. Pelaksanaan Pelatihan}

Pelatihan ecoprint diikuti oleh UKM Uung Galuh pada 19 Maret 2018 di Universitas Bhayangkara, Surabaya. Workshop pembuatan batik dengan bahan pewarnaan alami (ecoprint) ini diselenggarakan oleh Komunitas Sahabat Bumi yaitu komunitas yang peduli pada keselamatan lingkungan dengan bekerjasama dengan Griya Amira di Surabaya.

Sedangkan pelatihan Asesoris dengan Teknik Sospeso dan Tembaga bakar diikuti oleh UKM Vitrie Accessories melalui pengrajin lain yang yaitu pemilik usaha asesoris NA-Collection yang sudah melakukan ekspor asesoris. Pelatihan dilakukan pada pada April 2018. 
Website : http://dayamas.unmermadiun.ac.id/index.php/dayamas

\section{B. Metode Pelatihan}

1) Tahapan Pembuatan Batik Eco-print

Tahap pembuatan batik ecoprint adalah sebagai berikut: a) Proses Modan, yaitu kain yang akan dibatik dimodan dahulu (dicelup dalam air sabun seperti sabun cuci serbuk dimana perbandingan sabun: air adalah 1 sdt sabun: 1 gayung air); b) Pemilihan Bahan Alam, pemilihan bahan alam seperti daun, bunga atau akar tanaman yang akan dibuat pola batik. Pilih bahan alam yang berpola menarik dan berwarna kuat seperti seledri, daun ketela, daun singkong, daun papaya, daun pucuk merah, kenikir, bunga aster, bunga kamboja dll; c) Penempelan, yaitu Meletakkan bahan di atas kain kemudian diplester supaya posisinya tidak bergeser. Bisa diselotip secara penuh menutupi daun atau bunga; d) Printing, yaitu mem balik posisi kain sehingga bagian belakang kain di atas. Kain di atas talenan kayu dan pukul-pukullah bagian daun tersebut dari sisi belakang dengan; e) Pengeringan Awal, yaitu mendiamkan kain minimal 1 jam. Setelah cukup kering (sekitar 1 jam) lepaskan selotipnya; f) Penguatan warna awal yaitu mengukus kain setelah digulung dan diikat, selama 1 jam. Setelah dikukus, selotip mudah dilepas. Warna batik akan lebih bagus dengan proses pengukusan, proses pengukusan; g) Penguatan warna awal yaitu dengan mencelupkan kain ke dalam air dicampur tawas, h) Tahap pengeringan akhir, yaitu kain dikeringkan dan disetrika.

2) Tahapan Pembuatan Asesoris Sospeso

Metode pelatihan asesoris Sospeso meliputi beberapa langkah yaitu: a) memilah perca bermotif (daun dan bunga) yang memiliki nilai seni bagus ketika dirangkai, b) menggunting pola motif perca, c) menempel perca motif pada mika tipis yang sudah diberi lem putih (lem rajawali) serta natar perca dan mika diberi kawat halus untuk membuat lekukan, d) menyetrika perca yang sudah diberi plastic dengan menutupi dengan kain sehingga plastic tidak meleleh., e) merangkai perca motif dengan kombinasi berbagai pernak pernik yang sesuai dengan selera seni, misalnya dengan tembaga bakar, clay, kayu, mutiara, borci dll. Berikut adalah gambaran dari strategi bundling untuk batik ecoprint dan asesoris sospeso.

\section{III.HASIL DAN PEMBAHASAN}

Setelah mengikuti pelatihan batik ecoprint, UKM Batik Ujung Galuh yang awalnya membuat batik jumputan lukis kemudian mengembangkan dengan membuat batik jumputan dikombinasi dengan ecoprint. Produk ecoprint dikemas menggunakan strategi bundling dengan produk asesoris Sospeso yang dibuat dari perca kain ecoprint. Strategi bundling adalah strategi memasarkan dua atau lebih produk dalam satu paket / gabungan (Simonin dan Ruth, 1995; Vamosiu, 2018).

Harapannya kedua jenis produk ini bisa saling menguatkan daya Tarik konsumen dalam bentuk bundling. Bundling dalam presentasi produk akan menimbulkan daya tarik yang lebih tinggi (Luo, Li, Feng, \& Chen, 2017; Rao et al., 2017), sehingga meningkatkan pembelian konsumen pada kedua jenis produk. Berikut contoh produk bundling dari kedua macam produk ini.

Strategi bundling telah membantu meningkakan penjualan kedua jenis produk UKM. Produksi yang dimulai bulan April 2018 sampai dengan awal Juli telah menghasilkan omzet akumulatif sebesar Rp 19 juta sebanyak 334 lembar kain). Product bundling bisa mengarah pada peningkatan segment pasar dari segmen rendah ke segme yang lebih tinggi (Xu et al., 2018), seperti yang dilakukan oleh kedua UKM ini.

Berikut adalah gambaran pelaksanaan strategi bundling antara batik ecoprint dengan asesoris sospeso.

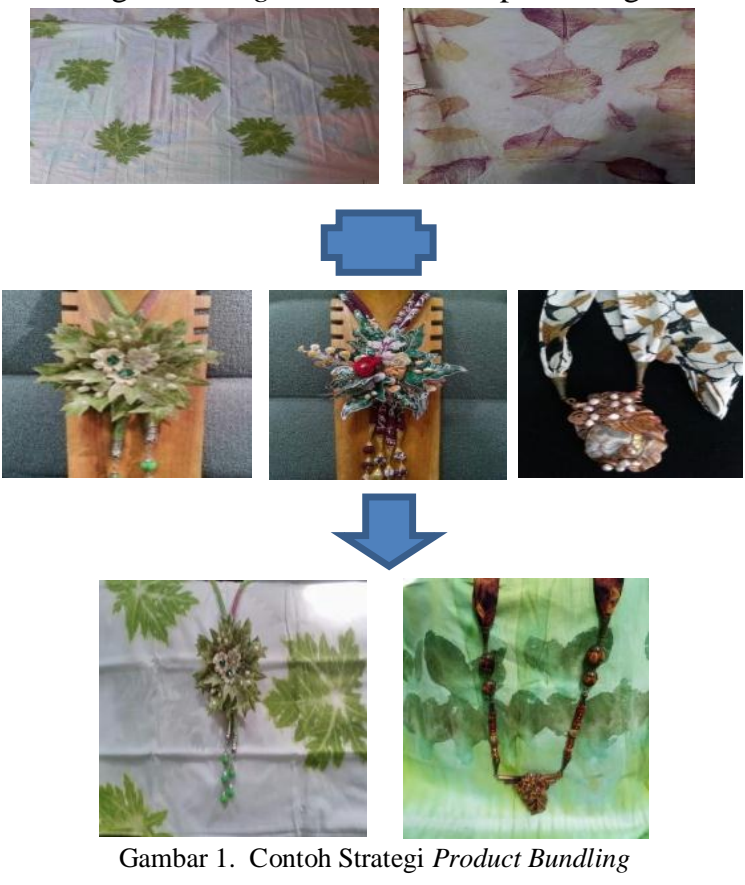


Website : http://dayamas.unmermadiun.ac.id/index.php/dayamas

Dampak strategi bundling telah meningkatkan minat pasar seperti yang tampak pada peningkatan penjualan. Minar kinsmen lebih kuat dibandingkan apabila produk batik sekedar dikemas secara individual tanpa memberikan akses asesoris dari sospeso. Omzet selama enam bulan ini diperoleh dari event pameran nasional dan kunjungan pembeli domestic maupun manca Negara. Namun omzet sebesar itu diperkirakan jumlah kain ecoprint sebesar 40\% dari omzet keseluruhan atau senilai Rp 7,6 juta.

Gambar 2 menunjukkan data penjualan UKM Ujung Galuh selama April-Juli 2018.

Tabel 2 Penjualan Batik April-Juli 2018

\begin{tabular}{|c|c|}
\hline Bulan & Nilai Penjualan \\
\hline April & 2.750 .000 \\
\hline Mei & 1.000 .000 \\
\hline Juni & 5.100 .000 \\
\hline Juli & 800.000 \\
\hline Total & 9.650 .000 \\
\hline $\begin{array}{c}\text { Rata2/ bulan } \\
\text { (April-Juli) }\end{array}$ & 3.860 .000 \\
\hline \multicolumn{2}{|c|}{ Sumber: Data Hasil Wawancara UKM } \\
\hline
\end{tabular}

Tabel 2 di atas adalah penjualan melalui beberapa pameran nasional dan kunjungan wisatawan baik domestic maupun asing yang dating langsung ke UKM Ujung Galuh. Pameran yang diikuti adalah Inacraft Jakarta, Program Ciputra Entrepreneur, Forum Koordinasi Kader Keluarga Berencana, Pekan Pelatihan Perbankan Mahasiswa Da Paz Timor Leste di STIE Perbanas Surabaya serta di Display Kerajinan Pemerintah Kota Surabaya. Adapun kunjungan wisatawan meliputi kunjungan dari Thailand, PKK Surabaya, kunjungan Universitas Airlangga. Selain itu pemilik UKM juga beberapa kali diundang di acara kewirausahaan mahasiswa STIE Perbanas Surabaya baik sharing dengan mahasiswa maupun mengikuti cara dengan display produk.

Dibandingkan dengan kinerja penjualan tahun-tahun sebelumnya terdapat kenaikan yang sangat bagus. Grafik 3.1 berikut menunjukkan kinerj apenjualan batik Ujung Galuh yang meningkat setelah dilakukan pengembangan motif ecoprint

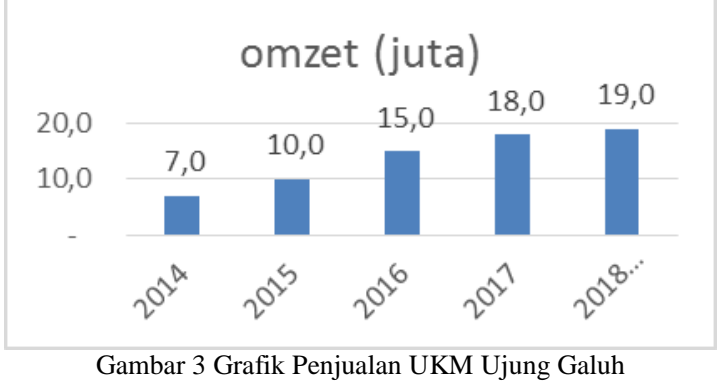

Berdasarkan grafik 3 terdapat peningkatan yang sangat signifikan pada penjualan batik jumputan Ujung Galuh yang per tahun rata-rata Rp. 12,5 juta namun pada tahun 2018 setelah pengembangan dengan motif ecoprint rata-rata penjualan selama enam bulan saja sudah mencapai Rata-rata Rp 3,86 Juta.

Terkait dengan hasil pelatihan yang dilakukan oleh UKM Vitrie yang memproduksi asesoris utama kalung dan bros juga mengalami kenaikan meskipun tidak sebaik batik ecoprint. Sebagai produk yang benar-benar baru bagi UKM ini, asesoris sospeso sudah cukup bagus dalam memberikan kontribusi penjulan yaitu selama April-Juli 2018 secara rata rata adalah 1 juta/ bulan (sebelumnya rata-rata 800 ribu/ bulan). Memang tidak sebesar kinerja batik, karena produksinya juga masih sangat kecil karena minat pasar terhadap asesoris tidak setinggi batik. Asesoris seos[eso sebenarnya tidak hnya untuk kalung atau bros, namun bisa diaplikasikan pada kerjaninan lain seperti tas dan dompet.

\section{IV.SIMPULAN DAN SARAN}

Simpulan dari program Pengabdian Masyarakat ini adalah sebagai berikut: a) Pengembangan batik ecoprint telah meningkatkan produktifitas UKM Ujung Galuh dengan sangat baik; b) Pengembangan desain asesoris sospeso meskipun tidak terlalu tinggi kinerjanya, namun telah meningkatkan produktifitas UKM Vitri.

Karena usaha seni adalah sangat terkait dengan talenta pemilik, maka kapasistas produk sangat berisiko tidak bisa memenuhi permintaan pasar. Untuk itu pemilik UKM harus mulai melakukan program shadow bagi beberapa orang untuk mengikuti kegiatan pemilik UKM ini sehingga mereka bisa menjadi tenaga produksi yang dapat memahami ekspresi seni yang akan dibuat.

\section{DAFTAR PUSTAKA}

Arikunto. 2013. Prosedur Penelitian Suatu Pendekatan Praktik. Rineka Cipta, Jakarta

Fleisher, Craig S. \& Bensoussan, B. E. (2003). Strategic and Competitive Analysis. New Jersey: Prentice Hall.

Ge, X., Zhang, Y., Qian, Y., \& Yuan, H. (2017). Effects of product characteristics on the bundling strategy implemented by recommendation systems. 14th International Conference on Services Systems and Services Management, ICSSSM 2017 - Proceedings. http://doi.org/10.1109/ICSSSM.2017.7996297

Kottler, P, Armstrong, G. (2018). Priciples of Marketing (17th ed.). UK: Pearson. 
Website : http://dayamas.unmermadiun.ac.id/index.php/dayamas

Luo, X., Li, M., Feng, N., \& Chen, F. (2017). Optimal Design on Customized Bundling Strategy of Information Goods for Customers with Two-Dimensional Heterogeneity. Asia-Pacific Journal of Operational Research, 34(2). http://doi.org/10.1142/S0217595917500075

Pearce, John A. \& Robinson, R. B. (2003). Strategic Management: Formulation, Implementation, and Control. New York: McGraw Hill.

Prasad, A., Venkatesh, R., \& Mahajan, V. (2017). Temporal product bundling with myopic and strategic consumers: Manifestations and relative effectiveness. Quantitative Marketing and Economics, 15(4), 341-368. http://doi.org/10.1007/s11129-017-9189-6

Rao, V. R., Russell, G. J., Bhargava, H., Cooke, A., Derdenger, T., Kim, H., .. Venkatesh, R. (2017). Emerging Trends in Product Bundling: Investigating Consumer Choice and Firm Behavior. Customer Needs and Solutions. http://doi.org/10.1007/s40547-017-0075-x

Schiffman, L.G, Wisenblit, J. L. (2015). Consumer Behavior. England: Pearson.

Sprott, D., Czellar, S., \& Spangenberg, E. (2009). The Importance of a General Measure of Brand Engagement on Market Behavior: Development and Validation of a Scale. Journal of Marketing Research, 46(1), 92-104. http://doi.org/10.1509/jmkr.46.1.92

Stremersch, S., \& Tellis, G. J. (2002). Strategic Bundling of Products and Prices: A New Synthesis for Marketing. Journal of Marketing, 66(1), 55-72. http://doi.org/10.1509/jmkg.66.1.55.18455

Xu, Q., Xu, B., Wang, P., \& He, Y. (2018). Bundling strategies for complementary products in a horizontal supply chain. Kybernetes, 47(6), 1158-1177. http://doi.org/10.1108/K-02-2017-0082

Ye, L., Xie, H., Wu, W., \& Lui, J. C. S. (2017). Mining customer valuations to optimize product bundling strategy. Proceedings - IEEE International Conference on Data Mining, ICDM, 2017-Novem, 555-564. http://doi.org/10.1109/ICDM.2017.65 